\title{
Inteligensi Manusia Sebagai Proses Hidup: Tinjauan Filsafati Atas Pemikiran Fritjof Capra
}

\author{
Althien J Pesurnay ${ }^{1}$ \\ ${ }^{1}$ Unit Matakuliah Humaniora, UKDW, Yogyakarta, Indonesia \\ E-mail: althienjohn@staff.ukdw.ac.id
}

\begin{abstract}
Abstrak
Perkembangan teknologi informasi dan komputer memunculkan kepercayaan naif bahwa kecerdasan komputer dapat melampuai kecerdasan manusia. Artikel ini menjelaskan konsep kecerdasan atau inteligensi manusia dalam pemikiran Fritjof Capra. Tujuannya untuk menawarkan pemahamaan tentang inteligensi manusia secara filosofis. Studi ini adalah studi pustaka dengan metode deskriptif dan interpretatif untuk mengkaji inteligensi manusia pada sumber primer The Tao of Physics. Inteligensi merupakan satu kemampuan manusia berhubungan dengan kegiatan, sifat, objek dari inteligensi manusia. Hasil menunjukkan bahwa melalui paradigma sistemik-holistik didapat pemahaman terdapat paralelisme antara cara inteligensi manusia memahami realitas melalui sains pada praktik fisika modern dan praktik spiritualisme timur. Kedua modus inteligensi manusia yang berbeda secara filosofis justru mendapati pengertian yang sama tentang hakikat realitas. Inteligensi manusia sebagai proses hidup merupakan sikap manusia terbuka bagi realitas atau (being) baik yang esensial maupun eksistensial. Secara prinsipil realitas merupakan satu kenyataan keterhubungan dalam jaringan relasi yang menyatu.
\end{abstract}

Kata Kunci: pengetahuan; inteligensi; filsafat manusia.

\begin{abstract}
In the era of computer and information technology there is a naive beliefs than artificial intelligence will be smarter than human. This article is showing the concept of human Intelligence as a human ability relates to the activities, properties, objects, nature of human beings and the knowledge itself. This is article is written to propose an understanding of human intelligence philosophically. This research is a bibliographical research and use descriptive and interpretative methods. The result shows human intelligence in Fritjof Capra's works offers new ideas of reality in the scheme of system theory and holistic paradigm. There is parallelism in two modes of intelligence to understand the world scientifically through modern physics and through intuition in eastern spiritualism. Human intelligence, although different in the mode of understanding reality, it shows both traditions are parallel in its principles. Human intelligence is understood as living process. Human Intelligence is openness to reality that is connected in a network of relations between parts as a whole. Being is the object of human intelligence in essential and existential categories understood in the living process.
\end{abstract}

Keyword: knowledge; intelligence; philosophical anthropology.

\section{Pendahuluan}

Kecerdasan atau inteligensi secara umum dimengerti sebagai kepandaian, kesempurnaan perkembangan akal budi, kemampuan berpikir akurat, menalar, memahami, dan bertindak dengan sengaja secara rasional. Inteligensi Manusia dalam ilmu pengetahuan sosial dan budaya dipahami secara lebih terbuka, plural, dan dinamis. Inteligensi manusia dipahami dalam konteks sosial dan budaya. Faktor-faktor Perkembangan inteligensi individu dengan berkembang dengan sangat unik dan khusus. Secara umum, inteligensi manusia dianggap majemuk sehingga tampak dengan banyak ciri dan bentuknya. Literatur ilmu psikologi dasar umumnya menjelaskan inteligensi atau kecerdasan ke dalam kategori dan corak kecerdasan yang majemuk. 
Kecerdasan Majemuk (Multiple intelligence) yang menjadi sudah umum ini masih sering terlupakan atau bahkan diabaikan sebagai dasar memahami kemampuan mengetahui manusia. Oleh sebab itu, agar pengetahuan tentang inteligensi manusia dapat diperluas menjadi pengetahuan umum maka perlu mendapat kajian terus-menerus. Penelitian keilmuan sosial dan budaya yang luas dan menyeluruh tentang inteligensi manusia perlu diperbanyak dan didiseminasi ke bidang-bidang yang strategis terkait pengembangan pendidikan dan bidang kebudayaan yang lainnya. Indonesia memerlukan fondasi kajian dan penelitian sosial budaya untuk mendapatkan pemahaman yang kokoh sebagai dasar percepatan indeks pembangunan manusia. Alasan lain untuk merancang strategi kebudayaan diperlukan kesadaran bahwa manusia merupakan makhluk multi dimensional yang kompleks.

Pemahaman tentang inteligensi yang naif berlaku dominan diterima dan dipercayai khalayak umum. Masyarakat umumnya menggunakan ukuran inteligensia tersebut untuk mengukur inteligensi manusia yang unik dan majemuk. Praktek pengukuran kecerdasan manusia sering terjebak pada satu aspek inteligensi saja, yakni kemampuan matematis, analitis, mengingat, dan mengerjakan soal-soal secara cepat. Model ukuran tersebut berbeda jauh dari hasil kajian inteligensi manusia dalam penelitian ini. Inteligensi manusia yang dikaji disini berangkat dari asumsi bahwa inteligensi manusia lebih luas dari ukuran-ukuran-ukuran tersebut. Pemahaman dan ukuran inteligensi yang naif ini juga berkembang dan mempengaruhi pengembangan teknologi informasi dan ilmu komputer. Komputer pada awalnya dianggap cerdas jika mampu mengerjakan dengan cepat perhitungan matematis, menjawab soal, dan mampu menampung informasi skala besar melampaui manusia. Pemahaman Inteligensi yang naif ini cenderung reduktif dan lalu terjebak dalam cara pandang dikotomis. Kecerdasan manusia lalu dihadaphadapkan dan dipertandingkan dengan mesin. Dikotomi tersebut tentu saja mereduksi dan mempersempit pemahaman tentang hakikat inteligensi manusia yang kaya dan kompleks. Pemahaman tentang kecerdasan manusia dan mesin tidak proporsional untuk dipertandingkan. Inteligensi mesin dan manusia berbeda secara ontologis. Memahami satu fenomena, konsep, atau gagasan memerlukan pemahan akan empat penyebaban (Kausa). Dari sudut pandang Aristotelian, penyebaban inteligensi manusia dan mesin secara material, formal, efisien dan finalisnya sangat berbeda. Pertimbangan gagasan penyebaban tersebut mengantarkan penelitian ini kepada alternatif pemahaman inteligensi manusia secara umum dan khusus. Penelitian ini hendak mengurai kembali kekusutan pemahaman inteligensi manusia. Kajian filsafat manusia mengindarkan pemahaman tentang inteligensi manusia dari kesimpulan yang naif. Kajian filsafat manusia membawa pemahaman bahwa mempertentangkan kecerdasan mesin dan manusia merupakan kesalahan logis sebab keduanya berbeda (kausa). Untuk mendapatkan pemahaman yang lebih dalam diperlukan kajian filosofis tentang hakikat dan makna dari cerdas atau inteligensi dalam arti yang manusiawi. Dasar tersebut penting sebab kita berangkat dengan proposisi bahwa manusia merupakan jangkar dari kebudayaan, kehidupan sosial bahkan realitasnya sendiri. Untuk memahami realitasnya dimulai dari memahami siapa atau apa manusia itu sendiri.

Pemahaman tentang inteligensi manusia secara filosofis untuk menyentuh dimensi ontologis membutuhkan tinjauan antropologis filosofis. Refleksi filsafat manusia sangat relevan sebab kajiannya khusus menyangkut aspek tubuh dan jiwa sebagai lokus inteligensi. Pemahaman inteligensi manusia secara sistematis menyasar segi-segi dasariah manusia seperti sosiokultural, individualitas (tubuh-jiwa) dan historisitas. Perbedaan manusia dengan makhluk lain adalah manusia mempunyai ciri istimewa, yaitu kemampuan berpikir yang ada dalam satu struktur dengan perasaan dan kehendaknya. Manusia adalah makhluk berkesadaran seperti yang disebut Aristoteles sebagai animale rationale (Suhartono, 2008). Manusia dalam kemenjadiannya membutuhkan kemampuan berpikir yang terus meningkat untuk berurusan dengan dunia. Inteligensi menjadi aspek penting manusia yang memungkinkan manusia mampu berbudaya, membangun ilmu pengetahuan dan teknologi arah peradaban manusia sejak sekian lama. Model- model yang dimiliki warga pribumi suatu budaya ditentukan oleh kedudukan warga itu dalam masyarakat, model itu berguna sebagai pedoman untuk mengambil tindakan, dan sebagai representasi aspirasi tentang dunia sebagaimana diketahui sebuah budaya. Pitt River mengatakan bahwa warga budaya tertentu menyusun klasifikasi menurut kategori-kategori dalam budaya digunakan untuk memberikan penjelasan tentang dunia dan untuk memutuskan bagaimana harus bertindak (Kaplan et al., 1999). Model kegiatan-kegiatan inteligensi manusia berbeda-beda di setiap kebudayaan dan peradaban. Dapat dilihat bagaimana unsur-unsur yang khusus dari manusia di berbagai belahan dunia yang berbeda menghasilkan keunikan eksistensi kebudayaannya masing-masing. Penentuan atas modus mengada manusia yang beragam itu memang ditentukan oleh berbagai macam faktor yang terdapat di lingkungan masing-masing. kondisi itu membawa dampak pada segi politik, ekonomi, sosial, budaya, seni, keagamaan, 
hingga ilmu pengetahuan dan pandangan hidup. Bermacam fenomena yang dihadapi manusia dalam kehidupannya itu memiliki hubungan erat dengan cara mengada, cara beradaptasi atau bahkan cara menguasai. Semua tindakan itu sudah mesti dan hampir selalu berdasar atas sebuah keputusan yang dikehendaki untuk menjadi jawaban dan jalan keluar dari atas problematika realita kehidupannya.

Kebutuhan mencari solusi atas segala permasalahan kehidupan bisa dimulai dari upaya memahami manusia dan hakikatnya. Secara khususus pemahaman tentang kemampuan, keunikan, dan perbedaannya dengan pengada-pengada lain. Kegiatan yang dianggap paling sentral di antaranya adalah mengerti dan mau. Pengertian dan pengkehendakan itu meresapi hampir semua kegiatan dan ekspresi manusia. Terutama memberi arti dan isi yang sungguh manusiawi (Bakker, 2001). Inteligensi atau kemampuan intelektual manusia menjadi penting untuk diteliti karena di situlah terletak potensi sebagai titik hubung kenyataan manusia dan dunianya. Bagaimana manusia menangkap realita, mengolah, menimbang, memutuskan, membangkitkan, memahaminya kembali secara terstruktur. Fase-fase mengolah data yang dicerapnya yang mana manusia berurusan kemudian menghasilkan pengetahuan dan pemahaman lebih yang memampukan dia membangun sebuah proyeksi akan masa depannya. Hari esok yang disongsong dengan kesediaan dan kesepian yang diidealkan. Keputusan dan tindakan manusia dalam realitasnya mengandaikan totalitas inteligensi dan sebuah landasan epistemologis yang tepat.

Dengan latar bekalang yang terletak urgensi untuk melakukan penelitian yang mengkaji konsep inteligensi manusia dalam pemikiran Fritjof Capra. Urgensinya untuk memberi kontribusi refleksi dan pemahamaan filosifis tentang inteligensi manusia. Sebagai langkah meluaskan pemahaman tentang topik inteligensi manusia dalam pemikiran Capra akan menambah bahan refleksi yang holistik dan sistemtik tentang manusia dan realitasnya. Penelitian filsafati bermaksud menemukan pemahaman tentang inteligensi dari sudut pandang filsafat manusia yang berguna sebagai jalan awal masuk kepada diskusi yang lebih luas seperti persoalan paradigma, ilmu dan pengetahuan. Capra menawarkan paralelisme antara kemampuan intuisi dalam mistisisme timur dan rasionalitas sains barat. Pemikiran Capra membuka lapis permasalahan tentang cara pandang baru dalam memahami hakikat dan realitas terdalam manusia. Dunia dipandang Capra sebagai jaringan kehidupan yang membutuhkan kerja sama antara sesama manusia dengan entitas lain yang non-manusia. Inteligensi manusia akan dipandang dari sudut pandang sistem-holistik.

\section{Metode}

Penulisan artikel ini menggunakan studi kepustakaan, yakni menelusuri buku dan jurnal tentang inteligensi secara umum, dan secara khusus inteligensi manusia dalam tinjuan filsafat manusia. Sumber buku utama sebagai objek material antara lain karya-karya Fritjof Capra pada topik filsafat pengetahuan (epistemologi), kognisi sains, dan sistem hidup. Karya-karya utama tentang topik ini antara lain The Tao of Pysics (1975) penerbit Shambala. Hidden Connection (2002) terbitan Doublday, The System of View Life terbitan Cambridge Press. The Turning Point (1982) terbitan Bantam Book. Jaring-jaring kehidupan (2001) penerbit pustaka pelajar yang diterjemahkan dari The Web of Life (1996). Penelitian ini dilakukan dengan langkah-langkah runut sebagai berikut. Pertama, inventarisasi untuk mengumpulkan sebanyak mungkin data kepustakaan dan karya yang berkaitan dengan dimensi inteligensi manusia pada pemikiran Fritjof Capra dalam telaah Filsafat Manusia. Kedua, identifikasi dan klasifikas bahan yang telah dikumpulkan untuk diidentifikasi dan dilakukan pemilahan agar dapat dipetakan antara data primer dan sekunder. Ketiga, langkah analisis data primer dan sekunder hasil pemilahan dianalisis secara kritis dengan menggunakan unsur metodis yang berlaku di kajian filsafati.

Metode analisis data yang dipakai dalam penelitian antara lain pertama, deskripsi sebagai upaya mengurai pokok dan permasalahan penelitiaan tentang inteligensi manusia dari sudut pandang filsafat manusia. Langkah berikutnya adalah interpretasi yang bertujuan untuk menyelami data yang telah terkumpul, khususnya pandangan Capra tentang inteligensi manusia hasil telaah filsafat manusia sehingga diperoleh suatu pemahaman yang cukup. Unsur holistika merupakan konsekuensi dari metode interpretasi dalam memahami pemikiran Fritjof Capra tentang dimensi inteligensi manusia secara menyeluruh dan secara khusus pada karya The Tao of Physics. Dari langkah-langkah metodis ini didapatkan suatu pemahaman yang lebih luas dan aktual tentang dimensi intelegensi manusia. 


\section{Hasil dan Pembahasan \\ a. Hasil}

Bagian ini akan memaparkan hasil analisis tentang inteligensi manusia dalam pemikran Fritjof Capra. Dari hasil interpretasi secara menyeluruh ditemukan pemahaman yang lebih luas dan aktual bagi pemahaman tentang inteligensi manusia. Pembahasan dibagi ke dalam tiga bagian pertama, filsafat manusia. Kedua, tubuh-jiwa sebagai lokus inteligensi manusia. Ketiga dimensi inteligensi manusia dalam karya The Tao of Physics.

\section{1) Filsafat Manusia}

Filsafat ialah sebuah model berpikir. Filsafat secara dasariah adalah pertanyaan kepada diri sendiri tentang sifat dasar dan hakikat kenyataan. Filsafat manusia merupakan subbagian atau cabang filsafat yang mengupas apa artinya menjadi manusia. Manusia mencoba mengartikulasikan sebaik mungkin apa sebenarnya makhluk yang disebut manusia (Louis, 1991). Filsafat manusia merupakan usaha memahami manusia seekstensif dan seintensif mungkin. Pemahaman manusia dalam kajian filsafat manusia diupayakan meliputi dan melingkupi semua aspeknya pada segala bidang dalam satu keseluruhan.

Penyelidikan fungsi dan kegiatan manusia haruslah dilihat secara menyeluruh pada semua taraf dan aspeknya sehingga dapat disimpulkan bahwa filsafat manusia adalah sebuah pembahasan hal-hal yang paling mendasar yang dilaksanakan secara rasional, kritis, ilmiah, dan refleksif. Refleksi di sini berarti pengetahuan manusia yang didapat dilengkungkan kembali kepada diri sendiri. Pengetahuan yang didapat dengan cara merenungkan kesadaran mengenai diri, kegiatan, dan mengenai objeknya. Objek formal filsafat manusia di sini adalah sudut pandang hakihat kenyataan manusia dan mengenai manusia secara keseluruhan (Bakker, 2001).

\section{2) Tubuh-Jiwa Sebagai Lokus Inteligensi Manusia}

Manusia baik dalam tradisi sains barat atau mistisisme timur merupakan manusia yang sama dan umum. Manusia yang susunan kodratnya terdiri dari tubuh dan jiwa. Dalam jiwa terdapat aspek akal, rasa, dan kehendak. Jiwa manusia bersifat spiritual, tidak berwujud, tidak dapat ditangkap diindera dibandingkan dengan tubuh yang bersifat kebendaan, dapat diindera. Tubuh manusia terdiri dari beberapa unsur-unsur benda mati, tumbuhan, binatang. Dalam pengkategorian berbeda manusia dibagi ke dalam empat taraf, yaitu dimulai dari yang terendah anorganis, vegetatif, sensitif, dan terakhir rasional (Bakker, 2001).

Dalam memahami kedudukan dan kegiatan inteligensi manusia harus dililihat secara menyeluruh pada semua taraf dan aspeknya. Semua taraf dan aspek ini selanjutnya dipandang sebagai satu keseluruhan. Inteligensi terjadi hampir di semua taraf manusia. Setiap taraf saling memuat dan memuncak pada taraf humanitas. Seorang manusia tidak mampu berkegiatan secara normal, seidealnya manusia apabila salah satu taraf terganggu. Kegiatan inteligensi sudah terjadi pada taraf vegetatif. Pada taraf itu sudah terdapat semacam kordinasi, sistem hidup. kordinasi ini membentuk satu kesatuan kerja (Bakker, 2001). Walaupun kordinasi dan fungsi masih sangat lemah namun dari taraf ini dapat ditemukan aktifitas hidup. Taraf sensitif pada tataran yang lebih tinggi memiliki sistem koordinasi dan subordinasi yang lebih baik. Fungsi masing-masing bagian dibagi secara unik dan khusus.

Pada taraf humanitas atau rasional inteligensi dalam arti yang manusiawi berkedudukan. Pada struktur ini taraf-taraf sebelum mencapai penyempurnaannya. Terdapat fungsi kordinasi utama, yaitu rasio. Disini manusia mampu berpikir secara analitis, simbolik, dan abstrak. Pengetahuan didapat manusia lewat kekuatan pikiran. Fungsi pikiran rasional kemudian sangat berguna bagi perkembangan pemikiran pada peradaban kuno hingga era sains modern. Rasio sebagai kekuatan pikiran pada sains dipakai untuk membedakan, membagi, membandingkan, mengukur dan mengkategorikan. Pikiran rasional sejak zaman dahulu dianggap sebagai salah satu aspek dari jiwa atau roh yang abadi. Terdapat pula di dalam jiwa manusia.

Taraf humanitas ini menjadi taraf utama, di mana potensi manusia diaktualisasi pada level yang sangat tinggi. Pada taraf ini, pikiran rasional bukan satu-satunya modus mengetahui yang berperan. Pada taraf humanitas, manusia juga dimampukan untuk memiliki pengetahuan spiritual. Manusia dimampukan mengaktualkan fungsi rohaninya. Manusia mampu masuk dalam dimensi batiniah. Lewat praktek spiritual manusia mendapat pengalaman khusus yang berbeda dari apa yang diperoleh secara empiris dan dipikirkan oleh rasio. Kenyataan yang dijumpai dalam pengalaman tersebut menembus tataran transendental atau supra-inderawi. 
Intuisi dan rasio memang berbeda ciri dan fungsi secara definitif. Intuisi terkhususnya dianggap berasal dari dimensi rohaniah manusia. Intuisi dalam kepenuhannya disebut sebagai roh murni. Selain pikiran dan rasio, manusia pun memiliki intuisi yang bersumber dari dimensi rohaniah manusia. Ide tentang roh dan jiwa sejak jaman dulu diungkapkan dalam bahasa kiasan sebagai nafas kehidupan. Psyche, Anima, Atman, Pneumena, spiritus, ruah kesemuanya ini memiliki arti yang sama, yaitu nafas. Kognisi ataupun inteligensi manusia jauh lebih luas dari pada pikiran rasional (Capra, 1996). Hal itu dikarenakan kognisi yang konotatif dengan inteligensi manusia meliputi seluruh proses kehidupan.

Kehidupan manusia secara eksistensial merupakan proses mengetahui. Dalam kemenjadian, manusia berupaya untuk terus mengetahui, membuka ruang-ruang kenyataan yang sebelumnya belum pernah didekati. Proses mengada manusia tidak dapat dipisahakan dari proses mengetahui. Dinamika yang progresif dari kehidupan manusia adalah proses inteligensi itu sendiri. Inteligensi manusia merupakan sikap dan keterbukaan manusia akan ada. Keterbukaan ada realitas sebagai ada eksistensial dan sekaligus esensial. Inteligensi manusia merupakan kemampuan untuk mengenal segala-galanya, kecakapan untuk mengetahui seluas-luasnya. Inteligensi dimiliki manusia karena objek-objek pengetahuan manusia adalah ada (being) itu sendiri. Apa yang dilakukan manusia dalam kebudayaannya, baik itu produk budaya ataupun arah budayannya tidak lepas inteligensinya sebagai proses kognisi.

\section{3) Inteligensi Manusia dalam Karya The Tao of Physics}

Filsafat pengetahuan yang berhubungan dengan inteligensi manusia di era klasik berorientasi pada kebenaran llahi dengan berdasar pada doktrin kebenaran mutlak dan rasionalisme manusia serta bersesuaian dengan kebenaran spiritual. Epistemologi pengetahuan modern yang berorientasi pada kebenaran manusiawi dengan rasionalisme obyektif sebagai satu-satunya sumber kebenaran (Muhtamar \& Ashri, 2020). Memahami manusia membutuhkan satu kerangka epistemologi yang mendasari paradigma baru. Capra hadir dengan paradigma holistik-sistemik. Capra berusaha menggabungkan epistemologi pengetahuan klasik yang berorientasi pada kebenaran llahi dengan berdasar pada doktrin kebenaran mutlak dan rasionalisme manusia serta bersesuaian dengan kebenaran spiritual. Holistik dan sistemik artinya mengacu pada dasar mistisime timur dan juga sains barat. Manusia baik dalam tradisi sains barat ataupun mistisisme timur merupakan manusia yang sama dan umum. Manusia yang susunan kodratnya terdiri dari tubuh dan jiwa. Dalam jiwa terdapat aspek akal, rasa, dan kehendak. Jiwa manusia bersifat spiritual, tidak berwujud, tidak dapat ditangkap diindera dibandingkan dengan tubuh yang bersifat kebendaan, dapat diindera. Tubuh manusia terdiri dari beberapa unsur-unsur benda mati, tumbuhan, dan binatang. Dalam pengkategorian berbeda manusia dibagi ke dalam empat taraf yaitu, dimulai dari yang terendah anorganis, vegetatif, sensitif, dan terakhir rasional (Hadi, 1996).

Dalam memahami kedudukan dan kegiatan inteligensi, manusia harus dipandang secara menyeluruh pada semua taraf dan aspeknya. Semua taraf dan aspek ini selanjutnya dipandang sebagai satu keseluruhan. Inteligensi terjadi hampir di semua taraf manusia. Setiap taraf saling memuat dan memuncak pada taraf humanitas. Seorang manusia tidak mampu berkegiatan secara normal, seidealnya manusia apabila salah satu taraf terganggu. Kegiatan inteligensi sudah terjadi pada taraf vegetatif. Pada taraf itu sudah terdapat semacam kordinasi, sistem hidup. kordinasi ini membentuk satu kesatuan kerja. Walaupun kordinasi dan fungsi masih sangat lemah namun dari taraf ini dapat ditemukan aktifitas hidup. Taraf sensitif pada tataran yang lebih tinggi memiliki sistem koordinasi dan subordinasi yang lebih baik. Fungsi masing-masing bagian dibagi secara unik dan khusus.

Pada taraf humanitas atau rasional inteligensi dalam arti yang manusiawi berkedudukan. Pada struktur ini taraf-taraf sebelum mencapai penyempurnaannya. Terdapat fungsi kordinasi utama, yaitu rasio. Disini manusia mampu berpikir secara analitis, simbolik, dan abstrak. Pengetahuan didapat manusia lewat kekuatan pikiran. Fungsi pikiran rasional kemudian sangat berguna bagi perkembangan pemikiran pada peradaban kuno hingga era sains modern. Rasio sebagai kekuatan pikiran pada sains dipakai untuk membedakan, membagi, membandingkan, mengukur dan mengkategorikan. Pikiran rasional sejak zaman dahulu dianggap sebagai salah satu aspek dari jiwa atau roh yang abadi. Terdapat pula di dalam jiwa manusia

Taraf humanitas ini menjadi taraf utama di mana potensi manusia diaktualisasi pada level yang sangat tinggi. Pada taraf ini pikiran rasional bukan satu-satunya modus mengetahui yang 
berperan. Pada taraf humanitas manusia juga dimampukan untuk memiliki pengetahuan spiritual. Manusia dimampukan mengaktualkan fungsi rohaninya. Manusia mampu masuk dalam dimensi batiniah. Lewat praktek spiritual manusia mendapat pengalaman khusus yang berbeda dari apa yang diperoleh secara empiris dan dipikirkan oleh rasio. Kenyataan yang dijumpai dalam pengalaman tersebut menembus tataran transendental atau supra-inderawi.

Intuisi dan rasio memang berbeda ciri dan fungsi secara definitif. Intuisi terkhususnya dianggap berasal dari dimensi rohaniah manusia. Intuisi dalam kepenuhannya disebut sebagai roh murni. Selain pikiran dan rasio manusia pun memiliki intuisi yang bersumber dari dimensi rohaniah manusia. Ide tentang roh dan jiwa sejak jaman dulu diungkapkan dalam bahasa kiasan sebagai nafas kehidupan. Psyche, Anima, Atman, Pneumena, spiritus, ruah kesemuanya ini memiliki arti yang sama, yaitu nafas. Kognisi ataupun inteligensi manusia jauh lebih luas dari pada pikiran rasional. Hal itu dikarenakan kognisi yang konotatif dengan inteligensi manusia meliputi seluruh proses kehidupan.

Kehidupan manusia secara eksistensial merupakan proses mengetahui. Dalam kemenjadian, manusia berupaya untuk terus mengetahui, membuka ruang-ruang kenyataan yang sebelumnya belum pernah didekati. Proses mengada manusia tidak dapat dipisahakan dari proses mengetahui. Dinamika yang progresif dari kehidupan manusia adalah proses inteligensi itu sendiri. Inteligensi manusia merupakan sikap dan keterbukaan manusia akan ada. Keterbukaan ada realitas sebagai ada eksistensial dan sekaligus esensial. Inteligensi manusia merupakan kemampuan untuk mengenal segala-galanya, kecakapan untuk mengetahui seluas-luasnya. Inteligensi dimiliki manusia karena objek-objek pengetahuan manusia adalah ada (being) itu sendiri. Apa yang dilakukan manusia dalam kebudayaannya, baik itu produk budaya ataupun arah budayannya tak lepas inteligensinya dan proses kognisi. Inteligensi manusia dalam karya awal Capra The Tao of Physics secara implisit menerangkan bahwa objek pengetahuan manusia sangat luas dan dalam. Keluasan kenyataan dalam observasi fisika modern maupun pengetahuan mistik ditempuh lewat modus mengetahui yang berbeda. Ada (being) yang diobservasi dalam kedua tradisi yang berbeda ini membawa Capra pada satu kesimpulan bahwa kenyataan fisik material atau ada eksistensial adalah kenyataan satu dan menyeluruh. Kelihatan terpisah secara fisik namun hanya ideal dipahami dalam ketakterpisahaan itu. Dengan kondisi tersebut maka ada kebutuhan akan suatu cara pandang baru atau semacam mental shift dalam memahami realitas. Paradigma baru ilmu yang digagas Capra memiliki maksud dan tujuan untuk menjawab keterbatasan ilmu pengetahuan. Ada (being) sebagai sesuatu yang terbuka untuk dimengerti dan dipahami mengundang manusia untuk mendekatinya. Ada sebagai yang eksistensial dan esensial dalam paradigma baru dipahami sebagai hubungan satu ada yang menyuluruh, satu ada yang melingkupi semua. Kenyataan adalah kenyataan seluas segala kenyataan yang saling

terhubung dan tergantung.

Pemahaman tentang inteligensi khususnya inteligensi manusia dalam karya Capra selanjutnya dirumuskannya secara implisit lebih luas sebagai proses kehidupan. Sumbangsih pemikiran Capra lanjut diarahkan secara konkret untuk mejawab persoalan terkini yaitu krisismultidimensional. Dunia yang didominasi cara pandang materialistik mekanis ini perlu diubah kedudukannya menuju paradigma yang didasarkan pada kesalinghubungan (interconnectedness), kesalingtergantungan (interdependent) esensial fenomena fisik material, biologis, psikologis, sosial dan kultural (Capra, 1982). Refleksi dan penelusuran inteligensi manusia dalam karya The Tao of Physics dan karya lainnya berguna meluruskan jalan bagi pemahaman yang lebih luas tentang kenyataan, tentang cara pandang baru dalam melihat kenyataan. Capra meninjau temuan-temuan besar sains modern untuk mendapatkan paradigma baru. Metode sains modern mensyaratkan pengamatan sistematis atas gejala yang dipelajari dan mencatat pengamatan-pengamatan ini sebagai bukti, atau data ilmiah. Metode ilmiah digunakan untuk memroduksi teori Imiah, setelah mengalami proses pengujian dan pengamatan lebih lanjut, dan jika mungkin, eksperiman tambahan, dan bahkan mampu memprediksi hasil-hasil eksperimen baru (Hidayatullah, 2019). Hasil eksprimen baru merupakan bahan refleksi bagi penelitian filsafati. Refleksi dilakukan demi mencapai suatu pemahan tentang dimensi nilai, pengetahuan, ataupun paradigma. Capra menghasilkan gagasan paradigma baru yang merupakan satu sintesa atas kearifan spiritual mistisisme timur dan sains modern dan segala praktik ilmiahnya.

Kontribusi pemikiran Capra ada pada uraiannya tentang modus memahami kenyataan pada tradisi fisika modern dan mistisisme timur yang memberi kejelasaan bahwa kenyataan bersifat terhubung dan menyeluruh. Kenyataan dipandang sebagai hubungan-hubungan 
dalam keseluruhan. Studi komparasi antara tradisi fisika dan mistisisme timur menghasilkan pemahaman yang mendasar bahwa setiap fenomena haruslah dipandang dalam relasinya (Capra, 1975). Hubungan saling tergantung dan saling terhubung menjadi simpul temu antara fisika di barat dan mistisisme di timur. Dalil-dalil yang telah disebut merupakan dasar paradigma baru yang digagas Capra lewat hasil observasinya atas sains, fisika modern dan pengalaman mistik.

Pada fisika modern terdapat pandangan tentang dunia yang secara esensial sama dengan mistisisme timur. Pengalaman langsung non-intelektual dengan realitas menjadi aspek penting dalam memahami kenyataan dalam mistisisme timur. Elemen-elemen dasar dunia yang diintepretasi dari mistik timur juga tampak dalam gambaran fundamental tentang kenyataan hasil penelitian fisika modern. Gagasan yang terpenting yang dapat ditarik dari mistisisme timur adalah kesadaran tentang penyatuan dan interaksi dari setiap benda dan peristiwa. Semua fenomena dalam dunia dianggap merupakan manifestasi-manifestasi sebuah kesatuan esensial. Semua benda dianggap sebagai bagian yang saling bergantung dan tidak dapat dipisahkan dari keseluruhan kosmis, sebagai manifestasi-manifestasi berbeda dari realitas yang sama. Tradisi timur benar-benar mengacu pada satu pandangan dasar bahwa realitas dapat dibagi, realitas termanifestasi ke dalam setiap benda namun tampak sebagai fragmen-fragmen.

\section{b. Pembahasan}

Kecerdasan atau inteligensi secara sederhana dan umum dimengerti sebagai kepandaian, kesempurnaan perkembangan akal budi, kemampuan berpikir akurat, menalar, memahami, dan bertindak dengan sengaja secara rasional. Inteligensi Manusia dalam ilmu pengetahuan sosial dan budaya dipahami secara lebih luas sehingga menghasilkan pengertian yang plural dan dinamis. Kondisi tersebut berangkat dari pengertian bahwa budaya, lingkungan sosial, dan perkembangan inteligensi individu berkembang dengan pengaruh lokus secara sangat unik dan khusus sehingga inteligensi manusia dirumuskan sebagai suatu kemampuan majemuk pada ciri dan bentuknya. Alsalhi (2020) mengikuti psikolog kenamaan Howard Gardner memahami kecerdasan dalam tujuh kategori dan corak. Kecerdasan Majemuk (Multiple intelligence) menjadi fondasi dasar bagi pemahaman tentang kemampuan belajar, kecerdasan pada bidang budaya terkhusus dunia pendidikan. Gagasan kemajemukan Inteligensi secara mendasar menekankan bahwa tiap individu belajar dan memahami secara unik dan khas (Abenti, 2020).

Pemahaman tentang inteligensi yang perlu dikoreksi adalah pemahaman yang naif tentang inteligensi manusia. Pemahaman naif ini berlaku dan dominan menjadi kepercayaan umum. Pemahaman tersebut bahkan tampak berkembang pada kelompok pengembangan teknologi informasi dan ilmu komputer. Pemahaman tentang kecerdasan buatan atau yang dikenal sebagai Al (artificial intelligence) dipercaya telah melampaui inteligensi manusia. Wacana tersebut berlaku pada pengembang Al pada paruh kedua abad dua puluh hingga sekarang. Konsekuensi dari paradigma tersebut hadir dikotomi antara kecerdasan manusia dan $\operatorname{mesin}(\mathrm{Al})$.

Terminologi yang digunakan para pakar Al untuk menjelaskan ukuran kemampuan Al yang menunjukkan kualitas dan level inteligensia mesin yakni strong Al dan weak Al. Istilah strong Al berarti kemampuan mesin yang memiliki corak menyamai kemampuan kognisi manusia. Istilah tersebut secara implisit menunjukkan definisi yang dikotomis antara inteligensi manusia dan teknologi. Ilmuan dan pengembang teknologi yang terkini hendak bergerak melampaui paradigma tersebut. Harapan dan prediksi para peneliti dan pengembang Al akhirakhir ini menggali juga sumber-sumber dari ilmu sosial dan budaya. Refleksi tentang cerdas diperluas hingga sampai pada kesimpulan bahwa pnyempurnaan teknologi cerdas membutuhkan kolaborasi dan sintesa antara manusia dan mesin ( $\mathrm{Ng}$ \& Leung, 2020).

IImu pengetahuan dikembangkan oleh para ilmuwan untuk mencapai kebenaran mengenai sesuatu hal. Kebenaran pada ilmu memberikan kepada manusia pemahaman tentang alam semesta, dunia sekelilingnya, masyarakat lingkungannya, dan, bahkan dirinya sendiri (Hidayatullah, 2019). Berdasarkan pemahaman tersebut ilmu sosial dan budaya dibutuhkan untuk menambal ruang-ruang kosong pemahaman para pakar Al dan teknologi informasi untuk menghasilkan suatu pemahaman yang lebih manusia. Harapan dan peran fungsional dan instrumental dari teknologi bagi peradaban manusia penting dengan catatan diberi pendasaran antropologis, etis, dan estetis. Topik-topik yang perlu diurai dan menjadi dasar bagi pengembangan Al adalah kajian-kajian filosofis dan interdisiplin tentang kesadaran, persoalan 
tubuh-jiwa (mind-body), kesadaran diri, dan kecerdasan. Pakar Al menyatakan hal yang sama bahwa inteligensi mesin membutuhkan pemahaman tentang consciousnes, Self-awareness, autonomous dan otonomi mesin ( $\mathrm{Ng}$ \& Leung, 2020). Wacana tersebut merupakan isu dan topikutama pada filsafat manusia, filsafat teknologi dan filsafat pikiran. Secara lebih spesifik penggalian filosofis terkait hasil-hasil dari-dari ilmu khusus ataupun yang interdisiplin.

Para peneliti dan pengembang Al di negara maju pada prosesnya terpaksa berkutat dengan pertanyaan-pertanyaan filosofis. Ilmuan komputer lantas terdorong untuk memikirkan isu-isu otonomi manusia dan robot (Asada, 2020). Artinya akan menyentuh secara luas ragam topik dan persoalan filosofis di atas. Pencarian atas jawaban-jawaban dari persoalan yang sangat filosofis tersebut tidak terjadi di level publik. Tinjauan filosofis ini bertujuan untuk mengisi kekurangan itu. Pada perspektif filsafat manusia Inteligensi manusia dipahami dalam taraf-taraf. Ururtan taraf dimulai dari yang terendah yakni taraf fisio-kemis, vegetatif, sensitif, dan puncaknya yakni humanitas. Kategori dan sistematisasi fenomena inteligensi penting untuk mengurai secara formal dan material inteligensi manusia. Inteligensi manusia terjadi hampir di semua taraf manusia. Setiap taraf saling mengandaikan. Setiap taraf saling memuat dan pada puncaknya termanifestasi pada taraf humanitas. Inteligensi manusia dimulai pada kedua terendah yakni taraf vegetatif. Pada taraf ini sudah muncul semacam koordinasi dalam sistem hidup. Terdapat aktivitas hidup di sini walaupun masih bersifat sederhana jika dibandingkan taraf di atasnya. Taraf sensitif merupakan taraf yang lebih tinggi dari vegetatif dan memiliki sistem koordinasi sistem hidup yang lebih kompleks.

Taraf humanitas merupakan level puncak inteligensi manusia. Potensi Inteligensi manusia di taraf ini diaktualisasi pada level sangat tinggi dan kompleks. Pikiran rasional pada taraf ini bukan merupakan modus utama. Pada taraf humanitas manusia melampaui rasionalitasnya dan dimampukan mengaktualkan fungsi spiritualnya. Manusia mampu mengaktualisasi dimensi batiniah. Dimensi spiritual dan batiniah ini menjadi corak khas bagi inteligensi manusia. Jika inteligensi dimengerti sebagai kemampuan rasional, kalkulasi, dan kapasitas menampung informasi maka terjadi reduksi dan penyempitan kekayaan multidimensional dari manusia. Hasil yang ditemukan dari penelitian ini adalah bahwa dimensi inteligensi dalam The Tao of Physics adalah suatu proses hidup yang menunjukkan kekayaan dimensi dari manusia. Taraf humanitas manusia bersifat rasional sekaligus juga bersifat bataniah. Inteligensi manusia dalam kedua tradisi dan praktik memahami realitas menunjukkan kemampuan dan capaian ke dasar realitas yang sama. Fisika barat dan mistisisme timur memiliki paralelitas.

Kedua tradisi tersebut berbeda modus inteligensinya. Kedua tradisi juga menunjukkan ciri dan sifat menangkap pengetahuan yang berbeda. Mistisisme timur melalui disiplin spiritual dan pengalaman spiritual memperoleh pengetahuan yang bersifat intuitif. Sedangkan fisika barat melalui observasi empiris dan rasio. Objek inteligensi dari mistisisme timur adalah realitas suprainderawi, atau ada (being) esensial. Tradisi fisika menyelidiki ada (being) eksistensial yaitu dunia materi sub-atom. Kedua tradisi tersebut berbeda dalam kegiatan, sifat, dan objeknya namun mencapai pemahaman yang sama yaitu bahwa alam semesta bahkan kenyataan seluasluasnya merupakan jaringan dari relasi antara berbagai bagian dari keseluruhan yang menyatu. Benda-benda di alam semesta (kosmos) memperoleh wujud dan bentuk melalui ketergantungan yang saling menguntungkan. Segala macam kenyataan fisik dan non-fisik tidak ditemukan dalam diri sendiri tetapi dalam kesatuan dan kesalingterhubungannya. Semua fenomena dalam dunia merupakan manifestasi-manifestasi satu kesatuan esensial. Semua benda merupakan sebagai bagian yang saling bergantung. Semua benda merupakan kesatuan yang tidak dapat dipisahkan dari keseluruhan kenyataan. Semua entitas spiritual dan material merupakan manifestasimanifestasi berbeda dari realitas yang sama

Pemahaman Inteligensi manusia dalam penelitian ini dipandang dari paradigma holistik dan sistemik. Kompleksitas inteligensi manusia hanya dapat dimengerti dalam inter-relasi tiap unsur dan taraf. Secara lebih luas bentuk inteligensi merupakan proses hidup dari saling ketergantungan dan saling keterhubungan dimensi-dimensi manusia. Pemahaman inteligensi yang sempit menghasilkan kepercayaan bahwa kecerdasan manusia akan dilampaui oleh kecerdasan mesin tidak memiliki dasar dan kedalaman pemahaman tentang manusia. Dikotomi tersebut cenderung mereduksi dan mempersempit pemahaman tentang hakikat manusia dan kekayaannya. Sebelum sampai pada pemahaman tentang kecerdasan dalam artian mesin perlu ada pendasaran filsafati tentang makna inteligensi sebagai proses hidup yang sistemik dan holistik. Penelitian yang dimulai memeriksa ciri, sifat-sifat dan objek inteligensi manusia yang mengerucut pada hakikat inteligensi. Relevansi refleksi filsafat manusia tentang tubuh dan jiwa sebagai lokus inteligensi telah menunjukkan sifat, kegiatan dan hakikat inteligensi manusia. Memahami hakikat inteligensi pada manusia berarti memahami segi sosio-kultural, 
individualitas (tubuh-jiwa) dan historisitas manusia. Pembahasan mengenai dimensi inteligensi manusia dalam karya-karya Fritjof Capra dilakukan dengan memakai analisis filsafat manusia. Hasilnya menunjukkan komparasi persamaan dan perbedaan dua tradisi dan praktik inteligensi. Komparasi ini menunjukkan perbedaan dan kesamaan esensial antara inteligensi manusia dalam tradisi mistisisme timur dan fisika barat. Inteligensi didefinisikan Fritjof Capra dengan terminologi yang khas yakni sebagai kegiatan kognisi. Inteligensi manusia dipahami dalam terminologi kognisi dalam arti luas yakni sebagai proses bertubuh sistem hidup yang mendunia. Inteligensi manusia merupakan proses hidup, proses mendunia manusia sebagai organisme.

\section{Simpulan}

Hakikat inteligensi manusia dalam pemikiran Fritjof Capra terletak pada sifat pengada yang terbuka bagi realitas. Inteligensi manusia dikonsepsikan sebagai kemampuan untuk mengetahui apa saja yang ada. Baik itu ada (being) esensial atau eksistensial, melalui observasi sains maupun pengalaman spiritual, dengan rasio maupun intuisi. Keterbukaan akan ada mengantarkan manusia pada pemahamaan akan keterhubunganan dan ketergantungan semua entitias dalam jaring-jaring kehidupan. Inteligensi yang paling manusiawi merupakan proses bertubuh sistem hidup yang mendunia sebagai organisme yang mencapai taraf humanitas. Inteligensi merupakan sikap terbuka kepada dunia namun mandiri dalam pengorganisasian hidup. Inteligensi adalah proses keterlibatan dengan dunia melalui pembentukan diri secara terus-menerus.

\section{Daftar Pustaka}

Abenti, H. F. (2020). How do I teach you? An examination of multiple intelligences and the impact on communication in the classroom. Language \& Communication, 73, 29-33.

Alsalhi, N. R. I. (2020). The representation of multiple intelligences in the science textbook and the extent of awareness of science teachers at the intermediate stage of this theory. Thinking Skills and Creativity, 38, 100706.

Asada, M. (2020). Rethinking Autonomy of Humans and Robots. Journal of Artificial Intelligence and Consciousness, 7(02), 141-153.

Bakker, A. (2001). Antropologi Metafisik. Kanisius.

Bakker, A. (2016). Metodologi Penelitian Filsafat. Kanisius.

Capra, F. (1975). The Tao of Physics: An Exploration of the Parallels between. Modern Physics and Eastern Mysticism.

Capra, F. (1982). The Turning Point. Bantam book.

Capra, F. (1996). The web of life. New York: Anchor. Doubleday.

Hadi, H. (1996). Jatidiri Manusia menurut Filsafat Proses. Kanisius.

Hidayatullah, S. (2019). Agama dan Sains: Sebuah Kajian Tentang Relasi dan Metodologi. Jurnal Filsafat, 29(1), 102-133.

Kaplan, D., Manners, A. A., \& Simatupang, L. (1999). Teori budaya. Pustaka Pelajar.

Louis, L. (1991). Esai Filsafat untuk Masa Kini. Pustaka Utama Graffiti.

Muhtamar, S., \& Ashri, M. (2020). Dikotomi Moral dan Hukum sebagai Problem Epistemologis dalam Konstitusi Modern. Jurnal Filsafat, 30(1), 123-149.

Ng, G. W., \& Leung, W. C. (2020). Strong Artificial Intelligence and Consciousness. Journal of Artificial Intelligence and Consciousness, 7(01), 63-72.

Suhartono, S. (2008). Dasar Dasar Filsafat. Ar-ruzz Media. 